\title{
Overweight in liver transplant recipients
}

\section{Excesso de peso em pacientes submetidos ao transplante hepático}

\author{
Lucilene Rezende Anastácio1; Michel C. de Angelis Pereira²; Eduardo G. Vilelä; Agnaldo S. Lima*; Maria Isabel T. D. Correia ${ }^{5}$
}

A B S T R A C T

\begin{abstract}
This review aims to describe the incidence and prevalence of overweight and obesity after liver transplantation and the consequences associated with it. Literature review consultation was conducted in Medline / PubMed, SciELO, EMBASE and LILACS, with the combination of the following keywords: liver transplantation, overweight, obesity, weight gain. Overweight is incident on more than $60 \%$ of patients undergoing liver transplantation and obesity rates exceed $20 \%$ in the first year after surgery, during which occurs the largest relative weight gain. Studies have shown that between $60 \%$ and $70 \%$ of patients undergoing liver transplantation are overweight after the third year, $90 \%$ with abdominal obesity. Associated factors are, among others, advanced age, family history of overweight and excess weight prior to liver disease. The contribution of immunosuppressive medication remains controversial. Some of the consequences of overweight are liver steatosis, steatohepatitis, diabetes mellitus, hypertension, dyslipidemia, cardiovascular disease and death.
\end{abstract}

Key words: Liver transplantation. Overweight. Obesity. Weight gain. Prevalence.

\section{INTRODUCTION}

Liver transplantation is the second most accomplished type of organ transplantation in Brazil, surpassed only by renal transplantation. In 2011, 1,492 liver transplants were performed by 55 teams registered across the nation ${ }^{1}$. It is often the only solution to acute and chronic liver failure, improving the quality of life of patients ${ }^{2}$ and increasing life expectancy ${ }^{3,4}$. Over the past two decades, rates of postliver transplantation survival increased to $85 \%$ in five years ${ }^{3}$ and to $56 \%$ after 20 years ${ }^{4}$, mainly due to advances in surgical techniques, in immune management and in pre, peri and postoperative care ${ }^{5}$.

However, the increased survival of patients undergoing liver transplantation was accompanied by the increasing prevalence of chronic diseases, usually higher than the prevalence found in the general population ${ }^{6}$. In this context, we highlight the excessive weight gain experienced by these patients, causing overweight and obesity. There are reports on obesity in $40 \%$ of the population already in the first post-transplant year ${ }^{7}$, and after three years of operation about $70 \%$ of patients have excess body weight ${ }^{8}$. Although no study has been able to demonstrate the relationship between overeating and posttransplant weight gain ${ }^{9-12}$, it is known that patients undergoing liver transplantation rediscover the appetite and pleasure of old eating habits after months of restrictions 13. Also, they feel better and are able to feed in appreciable quantities. At the same time, they feel eager to regain the weight lost during the months of waiting for transplantation ${ }^{14,15}$, since $75 \%$ of them are malnourished during this period ${ }^{16}$. Moreover, many patients do not return to work after surgery ${ }^{17}$ and those surviving for long periods have levels of daily physical activity significantly lower than the general population 4 . Besides these factors, all patients submitted to transplantation use immunosuppressive drugs, among which mainly cyclosporine or tacrolimus and, at least initially, corticosteroids. All these drugs are implicated in the genesis of posttransplant excessive weight gain and obesity ${ }^{18,19}$. Although this gain can not affect the statistics of survival of patients in the short term, it is certainly involved in the incidence of diabetes mellitus, dyslipidemia, hypertension and metabolic syndrome in this population 20. This morbidity exposes patients to increased risk of heart and kidney diseases, as well as nonalcoholic graft steatohepatitis. All have important consequences on longterm mortality ${ }^{21}$.

Thus, this revision work was elaborated in order to describe the weight gain, incidence and prevalence of overweight and obesity after liver transplantation, as well as the risk factors described for this morbidity and its consequences.

1. Post-Graduation Program in Adult Health, Faculty of Medicine, Federal University of Minas Gerais; 2. Post-Graduation Program in Human Nutrition and Health, Department of Food Science, Federal University of Lavras; 3. Alfa Institute of Gastroenterology, Clinics Hospital, Faculty of Medicine, Federal University of Minas Gerais. 


\section{WEIGHT GAIN, INCIDENCE AND PREVALENCE OF OVERWEIGHT AND OBESITY}

Weight gain after liver transplantation is crucial for the recovery of the patients' nutritional status. However, they usually gain more weight than they should. In a study of 597 patients 8, the average weight gain increased from $1.8 \mathrm{~kg} 9.5$ $\mathrm{kg}$ six months to three years after transplantation, leading to a prevalence of about $70 \%$ overweight (BMl> $25 \mathrm{~kg} / \mathrm{m}^{2}$ ).

The incidence of obesity in the first postoperative year ranges from $15.5 \%$ to $40.7 \% 7,8$, depending on the definition used, and continues to grow over the years after transplantation 7,8 . Some authors have reported rates of overweight of $60 \%$ on the second year ${ }^{11}$ and $70 \%$ on the third ${ }^{8}$. The works that have studied the incidence and prevalence of overweight and obesity after liver transplantation were summarizer in Table 1.

The first postoperative year seems to be responsible for most of the weight gained after the operation $8,10,22$. Patients seem to recover most of the weight lost during liver disease already in the first post-transplant year; $45 \%$ of them are overweight at the end of the first year versus $21 \%$ at the first post-transplant outpatient visit, and $43 \%$ prior to liver disease ${ }^{23}$.

Patients with longer transplant time have an even higher prevalence of overweight ${ }^{24}$. In a study with 143 patients undergoing liver transplantation with a median of four years since surgery, $58.1 \%$ were classified as having overweight by BMI and $69.9 \%$ by body composition. In the same study, $21 \%$ of individuals were classified as obese by BMI (e" $30 \mathrm{~kg} / \mathrm{m} 2$ ) and $37.8 \%$ by body composition 25 .

Although the prevalence of overweight and obesity are in clear ascendancy in recent years worldwide and in Brazil, yet the prevalence in the population undergoing transplantation is higher than in the general one. According to the latest data from the 20082009 Household Budget Survey, $50 \%$ of the adult Brazilian population has overweight, and $14.7 \%$, obesity 26 .

Still considering excess body weight, few studies have evaluated the prevalence of abdominal obesity in patients undergoing transplantation. In the study by Bianchi et al. ${ }^{27}$, with 296 patients, the prevalence of waist circumference greater than $88 \mathrm{~cm}$ for women and $102 \mathrm{~cm}$ for men was $32 \%{ }^{28}$. In the study by Anastácio et al. ${ }^{25}$, $41.5 \%$ of the individuals were thus classified, and $88 \%$ had some degree of abdominal obesity (waist circumference greater than $80 \mathrm{~cm}$ for women and $90 \mathrm{~cm}$ for men) 25 .

\section{FACTORS ASSOCIATED TO WEIGHT GAIN, OVERWEIGHT AND OBESITY}

The factors described are often older age $e^{8,29}$, family history of overweight, high BMI prior to the disease
8,22,30, post-transplant hypometabolism 8,10, post-transplant physical inactivity ${ }^{10}$, high donor BMI ${ }^{22}$, being married ${ }^{22,25}$, few hours slept ${ }^{25}$ and less dietary calcium intake ${ }^{25}$.

Some authors demonstrated greater weight gain in patients undergoing liver transplantation for chronic liver diseases compared with those who were transplanted due to fulminant hepatic failure ${ }^{8}$. This is consistent with the theory of regain of the weight lost while waiting for transplantation. The highest incidence of obesity has also been observed in patients with a history of overweight or higher BMI prior to liver transplantation 8,22,24,25,31.

The use of immunosuppressive drugs as a risk factor for excess weight after liver transplantation is still controversial. Some studies have found an association with cyclosporine ${ }^{27,32}$ and steroids ${ }^{22}$ and weight gain or being overweight, but not all 7,8,24.

The contribution of the lower energy expenditure for the formation of overweight and obesity in patients undergoing transplantation also remains unclear. Richardson et al. ${ }^{12}$ followed 23 patients after liver transplantation. They found a significant reduction in resting energy expenditure nine months after liver transplantation when compared with the pre-transplant period and controls. These authors also observed that the reduced resting energy expenditure after transplantation was an important predictor of increasing body fat mass after liver transplantation, though this association has not always been observed ${ }^{33}$. Although it is not yet known whether it does or does not decrease after transplantation, certainly, the total energy expenditure of these individuals is reduced postoperatively. Patients undergoing liver transplantation generally reduce the level of physical activity. Besides, they retire when seriously ill while on the waiting list for transplantation. After the operation, most do not return to work ${ }^{17}$ and a minority have reasonable levels of physical activity, $24 \%$ according to Painter et al. ${ }^{34}$. Other authors also found that levels of physical activity in patients undergoing liver transplantation are significantly lower than those of the general population ${ }^{4}$.

There are few data on food intake in liver transplant recipients. Nevertheless, none of the studies showed an association of dietary caloric intake with weight changes $8,10,11,25$. This is possibly due to the methods used, since intake is usually assessed at the time of data collection and not continuously. Studies on the role of steroids in weight gain suggest that they stimulate appetite and increase intake of high-fat candies and food ${ }^{35}$. Thus, patients tend to consume excess calories. In addition, patients undergoing liver transplantation feel freed from pre-transplant restrictions dietary and no longer have anorexia. They also have a higher sense of well-being and anxiety to regain the weight lost while waiting for transplantation ${ }^{15}$. Still, it is likely that patients return to old eating habits; the contribution of a history of overweight has been widely described as a risk factor for excessive weight gain and obesity $8,22,24,25,31$. 
Table 1 - Incidence and prevalence of excess weight, overweight and obesity after liver transplantation.

\begin{tabular}{|c|c|c|c|c|}
\hline AUTHORS & $\mathrm{N}$ & Local & TYPE OF STUDY & $\begin{array}{c}\text { Incidence / prevalence of excess weight, overweight and / or obesity } \\
\text { comments about weight gain / BMI }\end{array}$ \\
\hline Palmer et al. ${ }^{24}$ & 38 & USA & $\begin{array}{l}\text { Prospective; follow-up of } 2.3 \pm 1.9 \text { years post- } \\
\text { transplantation. }\end{array}$ & $\begin{array}{l}\text { Incidence of excess weight after transplantation in } 64.3 \% \text { of normal weight / underweight patients before surgery } \\
(n=18) \text {. All patients with excess weight before transplantation also had this condition after the operation }(n=11)\end{array}$ \\
\hline Munõz et al. ${ }^{11}$ & 21 & USA & $\begin{array}{l}\text { Prospective; follow-up to } 2.8 \pm 0.4 \text { years after } \\
\text { transplantation }\end{array}$ & $\begin{array}{l}\text { Incidence of excess weight after transplantation in } 67 \% \text { of normal weight / underweight patients before surgery }(n=14) \text {. } \\
\text { Incidence of obesity in } 43 \% \text { of normal weight / low weight patients before surgery }(n=9)\end{array}$ \\
\hline Stegall et al. ${ }^{7}$ & 123 & USA & $\begin{array}{l}\text { Retrospective, with survivors of liver } \\
\text { transplantation for at least one year }\end{array}$ & Incidence of obesity in $40.7 \%$ of the evaluated individuals one year after liver transplantation $(n=50)$ \\
\hline Everhart et al. ${ }^{22}$ & 774 & USA & $\begin{array}{l}\text { Prospective; follow-up till the second year Post- } \\
\text { transplant) }\end{array}$ & $\begin{array}{l}\text { Incidence of obesity two years after transplantation in } 21.6 \% \text { of patients who did not have this condition before surgery } \\
(\mathrm{n}=69) \text {. Average BMI of } 24.8 \mathrm{~kg} / \mathrm{m}^{2} \text { before transplantation, } 27.0 \mathrm{~kg} / \mathrm{m}^{2} \text { after one year, and } 28.1 \mathrm{~kg} / \mathrm{m}^{2} \text { after two years }\end{array}$ \\
\hline Richards et al. ${ }^{8}$ & 597 & England & $\begin{array}{l}\text { Prospective; follow-up till the third year Post- } \\
\text { transplant) }\end{array}$ & $\begin{array}{l}\text { Incidence of obesity in } 24 \%(n=76) \text { of non-obese patients before transplantation in the first year and } 31 \%(n=95) \text { in the } \\
\text { third year after the operation. Incidence of overweight three years after transplantation in } 67 \%(n=166) \text { of patients who } \\
\text { did not have this condition prior to operation }\end{array}$ \\
\hline Anastácio et al. ${ }^{25}$ & 143 & Brazil & $\begin{array}{l}\text { Cross-sectional, in patients with a median of four } \\
\text { years post-transplant }\end{array}$ & $\begin{array}{l}\text { Prevalence of overweight by BMI in } 58.1 \% \text {, in } 69.9 \% \text { by body composition and in } 88 \% \text { of patients by waist } \\
\text { circumference. Prevalence of obesity by BMI in } 21 \% \text { and in } 37.8 \% \text { by body composition }\end{array}$ \\
\hline
\end{tabular}




\section{IMPLICATIONS OF OVERWEIGHT AND OBESITY IN LIVER TRANSPLANTATION}

There are several implications of obesity in patients undergoing liver transplantation. Studies have shown that the obesity of donor and recipient may influence operative results ${ }^{36-42}$. Pre-obese patients are more likely, to develop primary graft dysfunction, delayed graft function after the operation and have increased risk of death ${ }^{36,37}$. These findings have not been universal, however, ${ }^{38}$.

Obesity can also affect the graft in the late postoperative period. In patients with general indications for liver transplantation, the incidence of steatosis ranges from $18 \%{ }^{43}$ to $40 \%{ }^{44}$ and the incidence of non-alcoholic steatohepatitis, from $9 \%{ }^{43}$ to $13 \%{ }^{44}$. Excess weight has been considered a risk factor for such types of involvement. Seo et al. ${ }^{43}$ observed that $83 \%$ of patients who developed nonalcoholic fatty liver disease had weight gain 10\% higher compared with pre-transplant BMI. Lim et al. ${ }^{44}$ also observed that liver transplant recipients who developed nonalcoholic steatohepatitis had significantly higher BMI $(32.5 \pm 4.3 \mathrm{~kg} /$ $\left.\mathrm{m}^{2}\right)$ than those who did not develop this condition (22.9 \pm $0.7 \mathrm{~kg} / \mathrm{m}^{2}$ ).

In addition, excessive weight gain and excess weight are certainly related to comorbidities, such as dia- betes, dyslipidemia, hypertension, metabolic syndrome, osteoarthritis and sleep apnea. They expose patients to increased risk of cardiovascular and renal diseases, and graft steatohepatitis ${ }^{20}$, as it happens in the general population. Moreover, higher rates of such conditions are found in patients moderately (BMI between $35-40 \mathrm{~kg} / \mathrm{m}^{2}$ ) and severely obese $\left(\mathrm{BMI}>40 \mathrm{~kg} / \mathrm{m}^{2}\right)$ after five years of operation ${ }^{45}$

\section{FINAL CONSIDERATIONS}

Patients undergoing liver transplantation experience excessive weight gain, especially in the first post-transplant year, increasing over the years. Factors described as associated with weight gain and excess posttransplant weight are multiple, but the contribution of immunosuppressive medication remains controversial. Overweight and obesity after liver transplantation are associated with different consequences, ranging from higher recipient mortality to the development of various conditions - fatty liver, steatohepatitis, diabetes, hypertension, dyslipidemia and cardiovascular disease. Programs to prevent excessive weight gain should be implemented by multidisciplinary teams in the centers where these patients are followed.

\section{R E S U M O}

Esta revisão tem por objetivo descrever a incidência e prevalência de excesso de peso, sobrepeso e obesidade pós-transplante hepático e as consequências associadas a ele. Foi realizada revisão bibliográfica com consulta nas bases Medline/Pubmed, SciELO, EMBASE, LILACS com o cruzamento dos seguintes descritores: transplante hepático; sobrepeso; obesidade; ganho de peso. $O$ excesso de peso é incidente em mais de $60 \%$ dos pacientes submetidos ao transplante hepático e as taxas de obesidade ultrapassam $20 \%$ já no primeiro ano do pós-operatório, período em que ocorre o maior ganho de peso relativo. Estudos revelaram que entre $60 \%$ e $70 \%$ dos pacientes submetidos ao transplante de fígado apresentam excesso de peso após o terceiro ano e quase $90 \%$ deles com obesidade abdominal. Os fatores associados são os mais variados, dentre os quais se destacam maior idade, história familiar de excesso de peso, excesso de peso anterior à doença hepática, dentre outros. A contribuição da medicação imunossupressora ainda permanece controversa. Dentre as consequências do excesso de peso estão a esteatose hepática, esteatohepatite, diabete melito, hipertensão, dislipidemias, doenças cardiovasculares e morte.

Descritores: Transplante de fígado. Sobrepeso. Obesidade. Ganho de peso. Prevalência.

\section{REFERENCES}

1. Associação Brasileira de Transplante de Órgãos (ABTO). Registro Brasileiro de Transplantes [Internet]. Janeiro/dezembro de 2010 RBT 2010;16(4):1-48. Acessado em: 29 out 2011. Disponível em: http://www.abto.org.br/abtov03/Upload/file/RBT/2010/1.pdf

2. Braun F, Teren K, Wilms P, Günther R, Allmann J, Broering DC, et al. Quality of life after liver transplantation. Transplant Proc. 2009;41(6):2564-6.

3. Adam R, Hoti E. Liver transplantation: the current situation. Semin Liver Dis. 2009;29(1):3-18.

4. Duffy JP, Kao K, Ko CY, Farmer DG, McDiarmid SV, Hong JC, et al Long-term patient outcome and quality of life after liver transplantation: analysis of 20-year survivors. Ann Surg. 2010;252(4):652-61.
5. Garcia VD. A política de transplantes no Brasil. Rev AMRIGS. 2006;50(4):313-20.

6. Simo KA, Sereika S, Bitner N, Newton KN, Gerber DA. Medical epidemiology of patients surviving ten years after liver transplantation. Clin Transplant. 2011;25(3):360-7.

7. Stegall MD, Everson G, Schroter G, Bilir B, Karrer F, Kam I. Metabolic complications after liver transplantation. Diabetes, hypercholesterolemia, hypertension, and obesity. Transplantation. 1995;60(9):1057-60.

8. Richards J, Gunson B, Johnson J, Neuberger J. Weight gain and obesity after liver transplantation. Transpl Int. 2005;18(4):461-6.

9. Anastacio LR, Ferreira LG, Ribeiro Hde S, Liboredo JC, Lima AS, Correia MI. Metabolic syndrome after liver transplantation: prevalence and predictive factors. Nutrition. Sep 2011;27(9):931 937. 
10. Krasnoff JB, Vintro AQ, Ascher NL, Bass NM, Paul SM, Dodd MJ, et al. A randomized trial of exercise and dietary counseling after liver transplantation. Am J Transplant. 2006;6(8):1896-905.

11. Munoz SJ, Deems RO, Moritz MJ, Martin P, Jarrell BE, Maddrey WC. Hyperlipidemia and obesity after orthotopic liver transplantation. Transplant Proc. 1991;23(1 Pt 2):1480-3.

12. Richardson RA, Garden OJ, Davidson HI. Reduction in energy expenditure after liver transplantation. Nutrition. 2001;17(78):585-9.

13. Heyman JK, Whitfield CJ, Brock KE, McCaughan GW, Donaghy AJ. Dietary protein intakes in patients with hepatic encephalopathy and cirrhosis: current practice in NSW and ACT. Med J Aust. 2006;185(10):542-3.

14. McCashland TM. Posttransplantation care: role of the primary care physician versus transplant center. Liver Transpl. 2001;7(11 Suppl 1):S2-12.

15. Reuben A. Long-term management of the liver transplant patient: diabetes, hyperlipidemia, and obesity. Liver Transpl. 2001;7(11 Suppl 1):S13-21.

16. Ferreira LG, Anastacio LR, Lima AS, Correia MI. Assessment of nutritional status of patients waiting for liver transplantation. Clin Transplant. 2011;25(2):248-54.

17. Saab S, Wiese C, Ibrahim AB, Peralta L, Durazo F, Han $S$, et al. Employment and quality of life in liver transplant recipients. Liver Transpl. 2007;13(9):1330-8.

18. McPartland KJ, Pomposelli JJ. Update on immunosuppressive drugs used in solid-organ transplantation and their nutrition implications. Nutr Clin Pract. 2007;22(5):467-73.

19. Mells G, Neuberger J. Long-term care of the liver allograft recipient. Semin Liver Dis. 2009;29(1):102-20.

20. Watt KD. Obesity and metabolic complications of liver transplantation. Liver Transpl. 2010;16(S2):S65-71.

21. Watt KD, Charlton MR. Metabolic syndrome and liver transplantation: a review and guide to management. J Hepatol. 2010;53(1):199-206.

22. Everhart JE, Lombardero $M$, Lake JR, Wiesner RH, Zetterman RK, Hoofnagle $\mathrm{JH}$. Weight change and obesity after liver transplantation: incidence and risk factors. Liver Transpl Surg. 1998;4(4):285-96

23. Anastácio LR, Ferreira LG, Ribeiro HS, Liboredo JC, Lima AS, Correia MITD. Excessive weight gain or just weight regain: what really happens after liver transplantation. JPEN - Journal of Enteral and Parenteral Nutrition. 2010;31:222.

24. Palmer M, Schaffner F, Thung SN. Excessive weight gain after liver transplantation. Transplantation. 1991;51(4):797-800.

25. Anastacio LR, Ferreira LG, de Sena Ribeiro H, Lima AS, Vilela EG, Toulson Davisson Correia MI. Body composition and overweight of liver transplant recipients. Transplantation. 2011;92(8):947-51.

26. Instituto Brasileiro de Geografia e Estatística (IBGE). Pesquisa de orçamentos familiares 2008-2009. Antropometria e estado nutricional de crianças, adolescentes e adultos no Brasil [Internet]. Rio de Janeiro: Instituto Brasileiro de Geografia e Estatística; 2010. Acessado em: 29 out 2011. Disponível em: http://www.ibge.gov.br/ home/estatistica/populacao/condicaodevida/pof/2008_2009/ POFpublicacao.pdf

27. Bianchi G, Marchesini G, Marzocchi R, Pinna AD, Zoli M. Metabolic syndrome in liver transplantation: relation to etiology and immunosuppression. Liver Transpl. 2008;14(11):1648-54.

28. WHO. Obesity: preventing and managing the global epidemic. Genebra: World Health Organization; 1998.

29. Anastacio LR, Lima AS, Toulson Davisson Correia MI. Metabolic syndrome and its components after liver transplantation: incidence, prevalence, risk factors, and implications. Clin Nutr. 2010;29(2):175-9.

30. Anastácio LR, Ferreira LG, Ribeiro HS, Liboredo JC, Lima AS, Correia MITD. Metabolic syndrome after liver transplantation: Prevalence and predictive factors. Nutrition. 2011.
31. Mor E, Facklam D, Hasse J, Sheiner P, Emre S, Schwartz $M$, et al. Weight gain and lipid profile changes in liver transplant recipients: long-term results of the American FK506 Multicenter Study. Transplant Proc. 1995;27(1):1126.

32. Canzanello VJ, Schwartz L, Taler SJ, Textor SC, Wiesner RH, Porayko MK, et al. Evolution of cardiovascular risk after liver transplantation: a comparison of cyclosporine $A$ and tacrolimus (FK506). Liver Transpl Surg. 1997;3(1):1-9.

33. Müller MJ, Loyal S, Schwarze M, Lobers J, Selberg O, Ringe B, et al. Resting energy expenditure and nutritional state in patients with liver cirrhosis before and after liver transplantation. Clin Nutr. 1994;13(3):145-52.

34. Painter P, Krasnoff J, Paul SM, Ascher NL. Physical activity and health-related quality of life in liver transplant recipients. Liver Transpl. 2001;7(3):213-9.

35. Dallman MF, la Fleur SE, Pecoraro NC, Gomez F, Houshyar H, Akana SF. Minireview: glucocorticoids-food intake, abdominal obesity, and wealthy nations in 2004. Endocrinology. 2004;145(6):2633-8.

36. Hillingso JG, Wettergren A, Hyoudo M, Kirkegaard P. Obesity increases mortality in liver transplantation-the Danish experience. Transpl Int. 2005;18(11):1231-5.

37. Pelletier SJ, Schaubel DE, Wei G, Englesbe MJ, Punch JD, Wolfe RA, et al. Effect of body mass index on the survival benefit of liver transplantation. Liver Transpl. 2007;13(12):1678-83.

38. Leonard J, Heimbach JK, Malinchoc M, Watt K, Charlton M. The impact of obesity on long-term outcomes in liver transplant recipients-results of the NIDDK liver transplant database. Am J Transplant. 2008;8(3):667-72.

39. Escartin A, Castro E, Dopazo C, Bueno J, Bilbao I, Margarit C. Analysis of discarded livers for transplantation. Transplant Proc. 2005;37(9):3859-60

40. Rinella ME, Alonso E, Rao S, Whitington P, Fryer J, Abecassis M, et al. Body mass index as a predictor of hepatic steatosis in living liver donors. Liver Transpl. 2001;7(5):409-14.

41. Hwang S, Lee SG, Jang SJ, Cho SH, Kim KH, Ahn CS, et al. The effect of donor weight reduction on hepatic steatosis for living donor liver transplantation. Liver Transpl. 2004;10(6):721-5.

42. Marsman WA, Wiesner RH, Rodriguez L, Batts KP, Porayko MK, Hay JE, et al. Use of fatty donor liver is associated with diminished early patient and graft survival. Transplantation. 1996;62(9):124651.

43. Seo S, Maganti K, Khehra M, Ramsamooj R, Tsodikov A, Bowlus C. De novo nonalcoholic fatty liver disease after liver transplantation. Liver Transpl. 2007;13(6):844-7.

44. Lim LG, Cheng CL, Wee A, Lim SG, Lee YM, Sutedja DS, et al. Prevalence and clinical associations of posttransplant fatty liver disease. Liver Int. 2007;27(1):76-80.

45. Nair S, Verma S, Thuluvath PJ. Obesity and its effect on survival in patients undergoing orthotopic liver transplantation in the United States. Hepatology. 2002;35(1):105-9.

Received on 25/07/2012

Accepted for publication 25/09/2012

Conflict of interest: None.

Source of funding: None.

How to cite this article:

Anastácio LR, Pereira MCA, Vilela EG, Lima AS, Correia MITD. Overweight in liver transplant recipients. Rev Col Bras Cir. [periódico na Internet] 2013;40(6). Disponível em URL: http://www.scielo.br/rcbc

Address for correspondence:

M. Isabel T. D. Correia

E-mail: isabel_correia@uol.com.br 